\title{
Planning for the Solid Waste Management of Central Park in New Capital Development of Afghanistan*
}

\author{
Sifatullah Mukhtar ${ }^{1 \#, ~ W a f a u r e h m a n ~ W a f a}{ }^{2}$, Haroon Halimzai ${ }^{3}$, Ajmal Khan Shams ${ }^{4}$ \\ ${ }^{1}$ Infrastructure Planning and Designing Division, Dehsabz-Barikab City Development Authority, Kabul, Afghanistan \\ ${ }^{2}$ Faculty of Environmental Sciences, University of Kabul, Kabul, Afghanistan \\ ${ }^{3}$ Afghanistan Agriculture Input Project, Ministry of Agriculture Irrigation and Livestock, Kabul, Afghanistan \\ ${ }^{4}$ Operation and Maintenance Division, Dehsabz-Barikab City Development Authority, Kabul, Afghanistan \\ Email: "envsigntst.sifat@gmail.com
}

Received 27 January 2016; accepted 9 May 2016; published 12 May 2016

Copyright (C) 2016 by authors and Scientific Research Publishing Inc.

This work is licensed under the Creative Commons Attribution International License (CC BY).

http://creativecommons.org/licenses/by/4.0/

c) (i) Open Access

\begin{abstract}
Kabul New City is a new capital development and a modern city development of Afghanistan covering total area of $740 \mathrm{~km}^{2}$. In 2009 Afghan cabinet approved developing New Capital to fulfill the requirement of growing population. For sustainable development, it has been planned to have a green belt and central park about 1298 hectares within the city. It is having positive impact on human health along with the economic, social and environmental benefits. Hence, for sustaining the urban parks, their proper maintenance is a foremost problem. The solid waste management is duly considered in planning stage of development, otherwise, it would encounter major challenges during operation and maintenance of Park. The projected waste generation in KNC park area is required to be assessed, therefore, surveys of Bagh-e-Babur in existing Kabul are carried out for the visitors' projection and solid waste generation. The highest visitors and waste were estimated in declining order of summer, spring, fall, and winter. Kabul New City Central Park results speculate that the total visitors' projection is going to be $6,745,313$ per year generating about 337 metric tons wastes/year $(0.05 \mathrm{~kg} / \mathrm{visitor} / \mathrm{day})$. 10 Vehicles of capacity $8 \mathrm{~m}^{3}$ are required to collect waste from central park towards the Transfer Station while 4 vehicles of $23 \mathrm{~m}^{3}$ are required for collection of waste from TS to Landfill. Moreover, 700 containers of 240 liters are required in the park. Furthermore, different sites were indicated in map for composting area where after the development it would be considered.
\end{abstract}

\section{Keywords}

Kabul New City, Central Park, Solid Waste Management, Operation and Maintenance

\footnotetext{
${ }^{*}$ Edited by Foxit Reader Copyright (C) by Foxit Software Company, 2005-2008 for Evaluation Only.

"Corresponding author.
}

How to cite this paper: Mukhtar, S., Wafa, W., Halimzai, H. and Shams, A.K. (2016) Planning for the Solid Waste Management of Central Park in New Capital Development of Afghanistan. Journal of Environmental Protection, 7, 805-815. 


\section{Introduction}

Advantages of Urban-Parks like economical values, health (Psychological and Physical) benefits, environmental and social benefits have been shown in numerous researches [1] [2]. Parks and open spaces enhance the excellence of life in the cities [3]. Urban parks fulfill important immaterial and non-consumptive human needs [4]. It reduces stress [5] and results in a good mental health [6] [7] provide sense of peacefulness \& tranquility [8] and reduce aggression [9]. Hospitalized patients who are able to view trees from their windows recover more quickly than those who see only buildings [10]. In addition, they show lower level of fear, fewer incivilities and less aggressive and violent behavior [11]. Furthermore, those who go to parks are in good physical health [1].

Parks increase social integration and interaction among neighbors [12] and promote social ties [9]. They provide get-together spot for kinfolk and social groups, as well as for individuals of various ages and economic status. Park generates tax and revenue [13]. In addition to increasing property values, open space boosts local economies by attracting tourists and supporting outdoor recreation. Nearness to park and water may influence the environmental and economic value [10]. It is purifier of air and reduces pollution and helps keep the air clean from harmful pollutants. Total suspended particles, sulfur dioxide $\left(\mathrm{SO}_{2}\right)$ and nitrogen dioxide $\left(\mathrm{NO}_{2}\right)$ could be removed at higher extent [14], and in addition, absorb carbon dioxide and other harmful greenhouse gases. It provides shelter from heat and wind and gives the aesthetic look to urban parks.

Unsecured circumstances in Afghanistan have severely damaged the natural environment. Side by side trees and highways in Kabul province and nearby areas were cut off due to war, with the destruction of irrigation system [15]. Modern planning of the greenery and parks in Afghanistan is in its infant stages. Despite the favorable conditions for plantation, fertile land and water resources in and around greater Kabul basin the parks and green belt have been experiencing descent due to improper or no maintenance.

Urban parks are crucial for sustainable development. Moreover, to make places greener, healthier, and more livable the greenways were recommended [16]. The Municipal Solid Waste (MSW) is an environmental concern in the cities, so the MSW management is a significant job that local governments as well as private corporations must take into account to maintain human healthiness, the environment and to preserve natural capitals [17]. However, maintenance and management of the parks are also important, otherwise, the aesthetic beauty would be lost. It includes one of the most critical maintenance and operation of solid waste management within parks. That is the reason in planning stage the proper management of solid waste has been taken duly into considerations.

This study aims the MSW management of central park with duly consideration during the planning and design stage. Furthermore, the calculations carried during this stage will clear the path during operation and maintenance. However, detailed design will be carried for the solid waste management of central park.

\section{Study Area}

Existing Kabul is the fastest population growing Province and Capital of Afghanistan. Due to returnees increase the population growth's stress of the Kabul, 5 million returnees returned to Afghanistan after 2002 [18]. It is approximately reached to 5.5 million in 2011 [18]. Existing Kabul will not be able to endure the burden of the population of Kabul; therefore, concept of KNC (Kabul New City) was raised. KNC is a modern city that will be built in Dehsabz district of Kabul. The concept has accepted in 2009 from Afghan cabinet to fulfill the requirement of increasing population [18]. Dehsabz-Barikab City Development Authority is the responsible authority for the city development. It has been planned to have a green built and a central park. The Study area of central park in $\mathrm{KNC}$ is situated between Lat Long $34.70094^{\circ} \mathrm{E} / 9.231582^{\circ} \mathrm{N}$ to $34.62035^{\circ} \mathrm{E} / 9.214788^{\circ} \mathrm{N}$ to $34.658102^{\circ} \mathrm{E} /$ $9.261378^{\circ} \mathrm{N}$ in Dehsabz district of Kabul, Afghanistan. The total area of central park is about 1298 hectares.

The KNC Central Park is designed to provide all the required facilities in a way to accommodate active and passive recreation and also provide means of revenue generation for the parks operations and maintenance. Land is allocated for different structures, functions and activities in a very efficient manner. One of the many components of the Central Park includes the Lake (Figure 1).

The KNC Central Park lake should include various entertainment activities and service facilities such as in /out gates, ticket booths, parking space, information desk/guide map, main lake, boats parking bays, lake island, park around the lake, circular light rail with railway stations, jogging tracks, cycle tracks, boat docking stations, tuck shops, picnic spots with lawns, flowerbeds, fancy street lights- dustbins, outdoor music etc., public toilets, prayers area. Preliminary detail of the central park is shown in Table 1. 


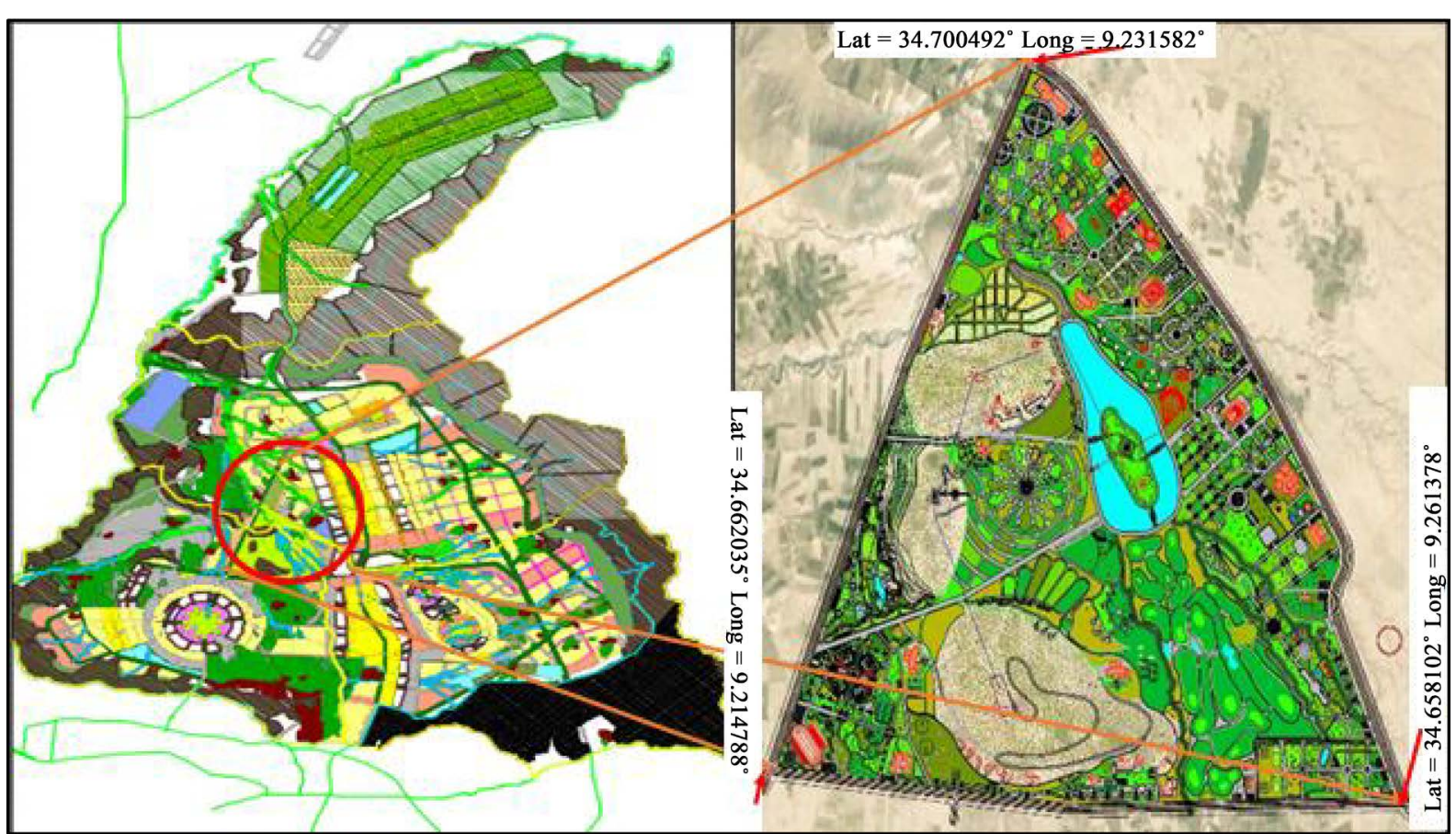

Figure 1. Central park with in the Kabul new city area.

Table 1. Central park preliminary information.

\begin{tabular}{ccc}
\hline No. & Central Park Items & Data \\
\hline 1 & Central Park Total Area & $1298 \mathrm{Ha}$ \\
2 & Area of 3 Hills in Central Park & $340 \mathrm{Ha}$ \\
3 & Estimated Planned Landscaped Area & $280 \mathrm{Ha}$ \\
4 & Estimated Non Landscaped Green Area & $400 \mathrm{Ha}$ \\
5 & Estimated Percentage of Facilities Sites to the Total CP Area & $30 \%$ \\
6 & Total No. of Facilities & 66 \\
7 & Total No. of Privately Funded Facilities & 32 \\
8 & Total No. of Publicly Funded Facilities & 19 \\
9 & Total No. of Concession Facilities & 9 \\
10 & Length of CP Railway & $4.5 \mathrm{Km}$ \\
11 & Area of CP Lake & $58 \mathrm{Ha}$ \\
13 & Area of CP Lake Island & $10 \mathrm{Ha}$ \\
\hline
\end{tabular}

\section{Method}

\subsection{Visitors Projection}

\subsubsection{Bagh-E-Babur}

Bagh-e-Babur is one of the parks in Existing Kabul where the data for the visitors' projection were taken. Moreover, each visitor has to pay (ticketing service) for entering into the park. The daily visitors' data records were taken from the responsible personnel for complete year 2014 and till May 2015.

\subsubsection{New-York}

New-York visitors' were surrogated from the New-York Case study [19] and manipulated according to the population of the KNC. The percentage of daily visitors was taken from the population of the New York that is 
about $8,405,837$ (simple cross multiplication was carried for instance $8,405,837$ total population is having 205,000 visitors in New York central Park, 1,500,000 would be having how much). For finding percentages cross multiplication were used (for instance $205,000 \times 100) / 8,405,837=2.44$ ). This founding was used for the KNC Park according to the population $(2.44 \% \times 1,500,000 / 8,405,837=36,582)$. The equation for the percentage and visitors projection were like

$$
V=P k \times V n / P n
$$

where $V=$ Visitor Projection in KNC; $P k=$ Population of KNC; $V n=$ Visitors of New York; $P n=$ Population of New York.

$$
N \%=V \times 100 / P
$$

where $N \%=$ Percentage of Visitors; $V=$ Visitors; $P=$ total population of New York City.

\subsection{Waste Generation in kg per Capita}

Waste generation were estimated for the year 2014 in the Bagh-e-Babur Kabul and divided by the visitors per day throughout the year 2014. The America typical waste in urban parks and landscape were $0.054 \mathrm{~kg} / \mathrm{capita} /$ day [20]. However, $0.05 \mathrm{~kg} / \mathrm{capita} /$ day were calculated using 2060 tons $/ 37,800,000$ visitors [21]. In Bagh-eBabur the estimated waste was observed to be $0.05 \mathrm{~kg} / \mathrm{capita} /$ day. Mathematically it can be derived as

$$
K g / \text { Capita } / \text { Day }=\frac{\sum \frac{K g}{d}}{\sum \frac{V}{d}}
$$

where $K g=$ Kilogram; $d=$ day; $V=$ visitors.

\subsubsection{Weighing Waste of Bagh-E-Babur}

Daily waste generated in Bagh-e-Babur was measured using a balance before it is discarded to the waste container.

\subsubsection{Methodology of Weighing of Waste of Bagh-E-Babur}

The waste were measured on the weekends (Thursday, Friday, Saturday, and Sunday) and on Weekdays (Monday Tuesday and Wednesday) of first week of every month throughout the year 2014.

\subsection{Statistical Analysis}

Statistical analysis was carried out using Ms. Excel.

\subsection{Drawing for the Central Park}

Drawing for the central park was made by using the AutoCAD 2013 software, ArcGIS 10.

\section{Results \& Discussion}

\subsection{Visitors Projection of Bagh-E-Babur}

Bagh-e-Baber is an Urban Historical Park Located in the central part of Kabul city having an Area of about 11 hectares. The visitors observed in the park were highest in the month of August with value of 71,455 . While lowest were observed in January with the value of 3857. The visitors observed were according to the gender (Men \& Women), Age (children under 12 and slightly above 12) and foreigners. The highest observed percentage was for men that were $53.7 \%$ while $23 \%$ were females. However the children fewer than 12 were $19.2 \%$ while the adolescence were $3.8 \%$. In contrast to all the visitors the value of the foreign visitors were lowest that was $0.3 \%$.

\subsection{Visitors in Bagh-E-Babur Correlation with the Temperature}

One year data collection of visitors shows that the numbers of visitors are extremely high in summer and spring 
seasons, in the result we can express that the increasing visitors are positively correlated to the temperature. Above tables shows the Bagh e Baber entry record of 2014.

According to Pearson Correlation matrix the visitors are very significantly Positive correlated to temperature in Bagh-e-Baber park $(r=0.82, p<0.001)$. It shows; when temperature is high the visitors' number increases in Bagh-e-Baber Park when the temperature is low in Kabul city the visitors' decreases.

The number of visitors increased during summer and spring seasons, if we look to the temperature record of Kabul city the temperature is high during April to October the number of visitor also increased during these months, but the number of visitors was high during march as well it was due to snow melting and first month of Afghan year Calendar, the people are traditionally visits attractive places in Afghanistan. Hence, the analyzing of the Bagh-e-Baber park visitors data, the KNC Park will have more visitors during summer session than winter session (Figure 2).

\subsection{Uniformity of KNC Park and New York Central Park}

The KNC Central Park is in planning stage and it will be more manipulated towards the realistic approach in detail in design stage. At planning stage the museum and recreational areas in $\mathrm{KNC}$ central park was planned that will be having cinemas, restaurants, and other entertainment stuff. In addition, the ground for football and cricket will also be created within the central park. The New York central park was almost containing the same recreational and other activities as planned in the KNC central park. It is worth note that the visitors' projection will be changed due to different factors including security, services in the area for the foreigner tourists, the entertainment facility for the local people and the recreational activities within the park.

The area of the Bagh-e-Babur is less than the KNC Park and New York Central Park comparatively. Moreover, single entertainment activity spot having that much visitors in Bagh-e-Babur (as shown in Figure 3). Secure environment and lack of recreational sites are also one of the most important matters for visitors' variations in Kabul city.

The New York Central Park Activities include Gaming and Exercises facility, and having Lawns (small and Larger), Landscape (hill, bridges etc.), Playgrounds, Refreshment spots (restaurants etc.), Recreational areas (zoo, carousel for children etc.) Sculptures \& Architectures, Water Bodies (pond, pool, lake, fountains) and Information centers (information kiosk, and police precinct). These mentioned varieties were considered for Art lovers, Athletes/Fitness Lovers, Birders, Dog Owners, Families, First time Visitors, History Lovers, and Nature Lovers [22].

The same planning has been carried for the KNC central park. The weather data and the activities are similar

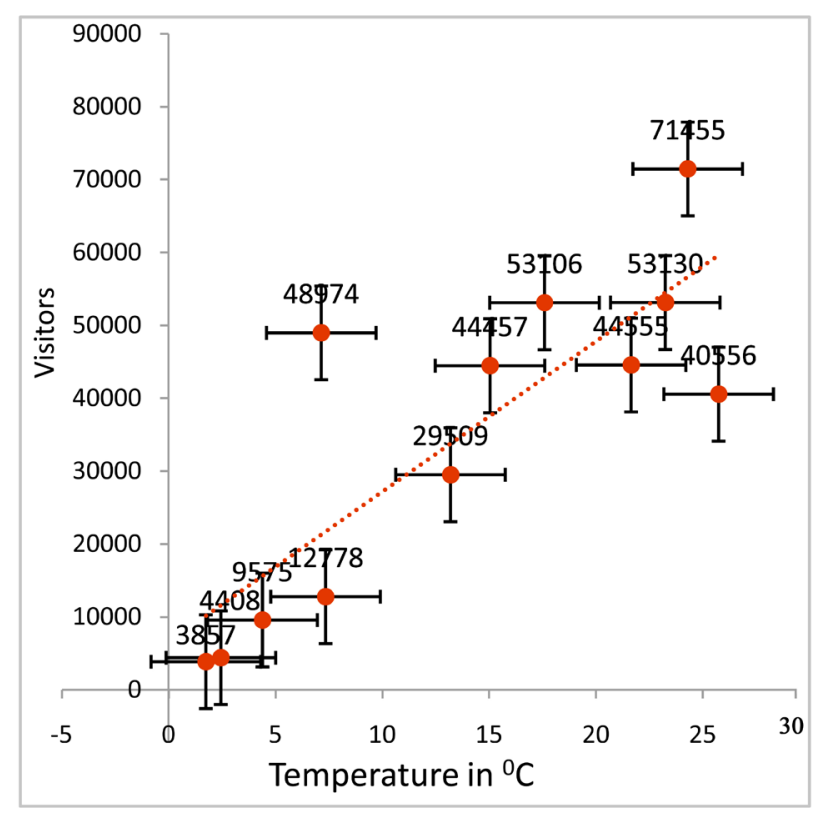

Figure 2. Correlation of temperature with visitors. 
to the New York Central Park that is the reason for the projection of the visitors according to the New York central park.

In addition to the weather condition were also considered to be slightly same both for the New York and for the Kabul. The weather degree in Centigrade was not more than 1.52 for the year 2014. The P value was observed to be 0.8 , as shown in Table 2. KNC is a long term development project of new capital till 2050 while environment is considered to be more secure. During that span the considered value must be like that of a secure area data. The data for the visitor's projection were estimated to be according to the New York Central Park.

\subsection{Visitor's Projection of KNC Central Park (Surrogate Approach)}

Visitor's projection for the Central park has been surrogated from the case study of New York Central Park due

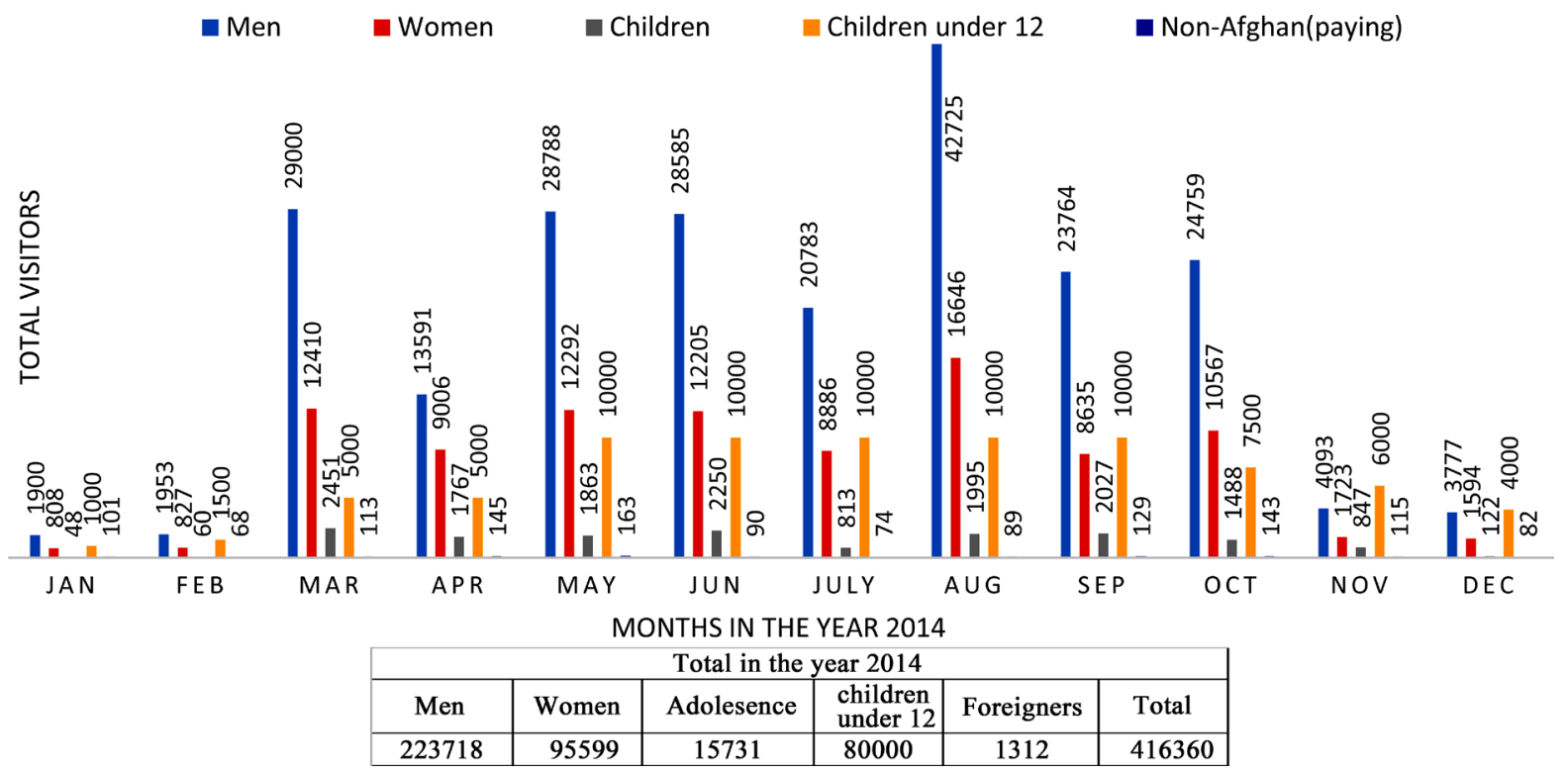

Figure 3. Visitors in Bagh-e-Babur according to age and gender in 2014.

Table 2. Monthly average temperature in centigrade values of New York and Kabul in 2014.

\begin{tabular}{cccc}
\hline Months & New York $^{*}$ & Kabul $^{* *}$ & Difference \\
\cline { 2 - 4 } & $\mathrm{A}$ & $\mathrm{B}$ & $\mathrm{B}-\mathrm{A}$ \\
\hline January & 0.27 & 1.75 & 1.48 \\
February & 1.77 & 2.45 & 0.68 \\
March & 5.84 & 7.15 & 1.31 \\
April & 11.68 & 13.2 & 1.52 \\
May & 16.92 & 17.6 & 0.68 \\
June & 21.93 & 23.25 & 1.32 \\
July & 24.79 & 25.75 & 0.96 \\
August & 24.02 & 24.3 & 0.28 \\
September & 19.98 & 21.65 & 1.67 \\
October & 13.89 & 15.05 & 1.16 \\
November & 8.77 & 7.35 & -1.42 \\
December & 3.06 & 4.4 & 1.34 \\
Mean & 12.74 & 13.66 & 0.91 \\
P(T $\leq$ t $)$ two-tail $^{* *}$ & 0.80283627 & & \\
\hline
\end{tabular}

Source: Online $[23]^{*}, \alpha=0.05$. 
to the uniformity of both parks. 37,800,000 visitors visited New York Central Park in year of 2010-2011 [19].

However, the KNC Central Park estimated results revealed that summer season having highest value of visitors in the central park, which were 218,598 visitors per week. It includes $70 \%$ from the local county/Province and $30 \%$ from other part of the county/province or foreigner visitors [19].

In contrast to the summer season the spring season has the second highest value of visitors almost 184,693 per week has been projected. Although the fall season estimated visitors were 145,435 per week. Despite the cold season the estimated numbers of visitors in winter were observed to be the lowest visitors 57,995 . In conclusion all the three seasons subsequently summer, spring and fall received highest visitors while the winter received lowest visitors comparatively in the central park. Table 3 shows the visitors projection in central park.

\begin{tabular}{ccc} 
Table 3. Central park preliminary information. & \\
\hline Month & Visitors & Temperature in ${ }^{\circ} \mathrm{C}$ \\
\hline Jan & 3857 & 1.75 \\
Feb & 4408 & 2.45 \\
Mar & 48,974 & 7.15 \\
Apr & 29,509 & 13.2 \\
May & 53,106 & 17.6 \\
Jun & 53,130 & 23.25 \\
July & 40,556 & 25.75 \\
Aug & 71,455 & 24.3 \\
Sep & 44,555 & 21.65 \\
Oct & 44,457 & 15.05 \\
Nov & 12,778 & 7.35 \\
Dec & 9575 & 4.4 \\
\hline
\end{tabular}

$\mathrm{n}=12, \mathrm{p}<0.05, \mathrm{r}=0.55^{*} ; \mathrm{p}=0.01, \mathrm{r}=0.68^{* *} ; \mathrm{p}=0.001, \mathrm{r}=0.80^{* * *}$.

\subsection{Waste Generation}

\subsubsection{Waste Generation in Bagh-E-Babur}

Solid Waste generation in Bagh-e-Babur was estimated to be about $0.05 \mathrm{~kg} /$ capita/day, it includes only the waste generated by the visitors. Typical density was assumed to be $130 \mathrm{~kg} / \mathrm{m}^{3}$ [2], where the total volume observed to be $157 \mathrm{~m}^{3} . \mathrm{Kg} / \mathrm{capita} /$ day was observed to be almost the same as calculated in New York Central Park [21]. Total visitors in Bagh-e-Babur were observed to be 416,360, with total annual waste generation of about 20,402 $\mathrm{kg}$ (Table 4).

\subsubsection{Waste Generation Estimation in KNC Central Park}

The more visitors projected calculation shows the highest waste generation estimation. The highest values were observed in weekends (2 days) in contrast to weekdays (5) weekly in all the four season of the year. The highest waste was estimated in declining order of summer, spring, fall, and winter. The waste generation considered is only for the outdoor in the central park (Not containing the restaurants etc. waste) (Table 5).

\subsection{Vehicles and Container Required According to the Capacity in KNC Central Park}

Average waste generation per week was estimated to be $10,930 \mathrm{~kg} / \mathrm{week}$. The total vehicles and containers required were estimated on basis of weekly waste. Total 14 vehicles are required if one trip per week is considered. It includes 10 vehicles that are required from central park to Transfer Station of about $8 \mathrm{~m}^{3}$ vehicles. While, 4 vehicles that are $23 \mathrm{~m}^{3}$ are required from TS to Landfill. The total required container of about 240 liter will be used which are required about 700 . During this planning stage it is taken to be that much however, the container size and the number may vary during the operation and maintenance with the real approach. Two containers in each site will be placed one for trash and one for the recyclable for onsite segregation of waste (Table 6, Table 7). 
Table 4. Waste generation in Bagh-e-Babur.

\begin{tabular}{cccccc}
\hline Total Visitors Per Year & Total Waste Per Year & $\mathrm{Kg} / \mathrm{Capita} /$ day & Density in $\mathrm{Kg} / \mathrm{m}^{3}$ & Total Volume & Total Visitors Per Year \\
\hline 416,360 & 20,402 & 0.05 & 130 & 157 & 416,360 \\
\hline
\end{tabular}

Table 5. Waste visitors projection and waste generation in central park.

\begin{tabular}{|c|c|c|c|c|c|c|}
\hline \multicolumn{4}{|c|}{ Visitors Projection in Central park } & \multicolumn{3}{|c|}{$\begin{array}{l}\text { Waste generation in Central Park in } \mathrm{Kg} \\
\quad \text { for } 1.5 \text { million population }\end{array}$} \\
\hline \multicolumn{2}{|l|}{ Summer } & \multicolumn{5}{|c|}{ Summer } \\
\hline & Total per week & Total per month & Per season & Total per week & Total per month & Per season \\
\hline $70 \%$ from the local people & 153,019 & 642,678 & $1,928,035$ & 7651 & 32,134 & 96,402 \\
\hline $30 \%$ from other part of the Province & 65,579 & 275,434 & 826,301 & 3279 & 13,772 & 41,315 \\
\hline Total & 218,598 & 918,112 & $2,754,336$ & 10,930 & 45,906 & 137,717 \\
\hline \multirow[t]{2}{*}{ Winter } & & \multicolumn{5}{|c|}{ Winter } \\
\hline & Total per week & Total per month & Per season & Total per week & Total per month & Per season \\
\hline $70 \%$ from the local people & 40,597 & 170,507 & 852,533 & 2030 & 8525 & 42,627 \\
\hline $30 \%$ from other part of the Province & 17,399 & 73,074 & 365,371 & 870 & 3654 & 18,269 \\
\hline Total & 57,995 & 243,581 & $1,217,904$ & 2900 & 12,179 & 60,895 \\
\hline \multirow[t]{2}{*}{ Fall } & & \multicolumn{5}{|c|}{ Fall } \\
\hline & Total per week & Total per month & Per season & Total per week & Total per month & Per season \\
\hline $70 \%$ from the local people & 101,804 & 427,578 & 855,156 & 5090 & 21,379 & 42,758 \\
\hline $30 \%$ from other part of the Province & 43,630 & 183,248 & 366,495 & 2182 & 9162 & 18,325 \\
\hline Total & 145,435 & 610,826 & $1,221,651$ & 7272 & 30,541 & 61,083 \\
\hline \multirow[t]{2}{*}{ Spring } & & \multicolumn{5}{|c|}{ Spring } \\
\hline & Total per week & Total per month & Per season & Total per week & Total per month & Per season \\
\hline $70 \%$ from the local people & 129,285 & 542,998 & $1,085,995$ & 6464 & 27,150 & 54,300 \\
\hline $30 \%$ from other part of the Province & 55,408 & 232,713 & 465,427 & 2770 & 11,636 & 23,271 \\
\hline \multirow[t]{3}{*}{ Total } & 184,693 & 775,711 & $1,551,422$ & 9235 & 38,786 & 77,571 \\
\hline & & & & & Total kg per year & 337,266 \\
\hline & & Grand Total & $6,745,313$ & & $\begin{array}{l}\text { Total metric tons } \\
\text { per year }\end{array}$ & 337 \\
\hline
\end{tabular}

Table 6. Vehicles required according to capacity.

\begin{tabular}{|c|c|c|c|c|c|}
\hline & \multicolumn{5}{|c|}{ Waste Transport for CP } \\
\hline & \multicolumn{5}{|c|}{ Vehicles Required according to the Capacity } \\
\hline & $\begin{array}{l}\text { Generated waste } \\
\mathrm{kg} / \text { week }\end{array}$ & $\begin{array}{l}\text { volume of waste } \\
\text { in } \mathrm{m}^{3}\end{array}$ & $\begin{array}{l}\text { Typical Density of } \\
\text { Solid waste }\end{array}$ & $\begin{array}{l}\text { Vehicle Capacity } \\
\qquad\left(\mathrm{m}^{3}\right)\end{array}$ & $\begin{array}{l}\text { Total }{ }^{*} \text { Vehicles } \\
\text { required }\end{array}$ \\
\hline $\begin{array}{l}\text { From Central Park to } \\
\text { Transfer Station }\end{array}$ & 10,930 & 84.07 & 130 & 8 & 10 \\
\hline From TS to Landfill & & 84.07 & 130 & 23 & 4 \\
\hline Total & & & & & 14 \\
\hline
\end{tabular}

${ }^{*} 1$ Trip/week is assumed to be for the waste towards the transfer station while 1 trip/day for the TS towards landfill.

Table 7. Waste containers required according to the capacity.

\begin{tabular}{|c|c|c|c|c|c|}
\hline \multirow[b]{3}{*}{$\begin{array}{c}\text { Total Allocated } \\
\text { Waste bins }\end{array}$} & \multicolumn{5}{|c|}{ Waste Container Calculation } \\
\hline & \multicolumn{5}{|c|}{ Containers Required according to the Capacity } \\
\hline & 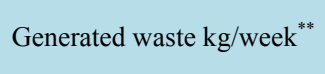 & $\begin{array}{l}\text { volume of } \\
\text { waste } \mathrm{m}^{3}\end{array}$ & $\begin{array}{l}\text { Typical Density } \\
\text { of Solid waste }\end{array}$ & $\begin{array}{c}\text { Container } \\
\text { Capacity }\left(\mathrm{m}^{3}\right)\end{array}$ & Total Containers \\
\hline For Trash & 10,930 & 84.07 & 130 & 0.24 & 350 \\
\hline For Recyclables & 10,930 & 84.07 & 130 & 0.24 & 350 \\
\hline Total & & & & & 700 \\
\hline
\end{tabular}

${ }^{* *}$ The generated waste/week is taken for the containers for Trash and for Recyclables. 


\subsection{Area for Composting in KNC Central Park}

Short term and long term composting locations sites were selected. For the initial composting method the composting will be carried in the embankment of the composting area while for the long run and after the feasibility study the sophisticated composting plant will be installed in the reserved area next to the transfer station site.

\subsection{Transfer Station Site in KNC Central Park}

Transfer station site were located in the area where all the waste will be collected and transferred from transfer station towards the landfill site (Figure 4).

\section{Conclusions}

Bagh-e-Babur Park in existing Kabul having total area is about 11 hectares with the total visitor of 416,360 per annum in the year 2014. Visitors in Bagh-e-Babur correlation to weather was significantly positive $(r=0.82, p<$ 0.001). Waste generation in Bagh-e-Babur was observed to be $23,586 \mathrm{~kg}$ per year. KNC's park visitors' projection was taken surrogate from New York central park, because of the recreational services and due to weather compatibility with mean difference of 0.91 and $\mathrm{p}$ value of 0.80 . Visitor's projection in KNC central park was speculated to be about $6,745,313$ for the whole year.

Total area for the KNC central park was planned to be about 1298 hectares. The solid waste generation is taken to be $0.05 \mathrm{~kg} / \mathrm{visitor} / \mathrm{day}$. However, at this stage the speculation in the context of this study we have come across some results and conclusions that include. Total 337 metric tons waste per year was estimated in the KNC central park. Total of 14 vehicles are required for the operation and maintenance of central park waste while. Total of 700 containers are required according to the capacity of waste estimated.

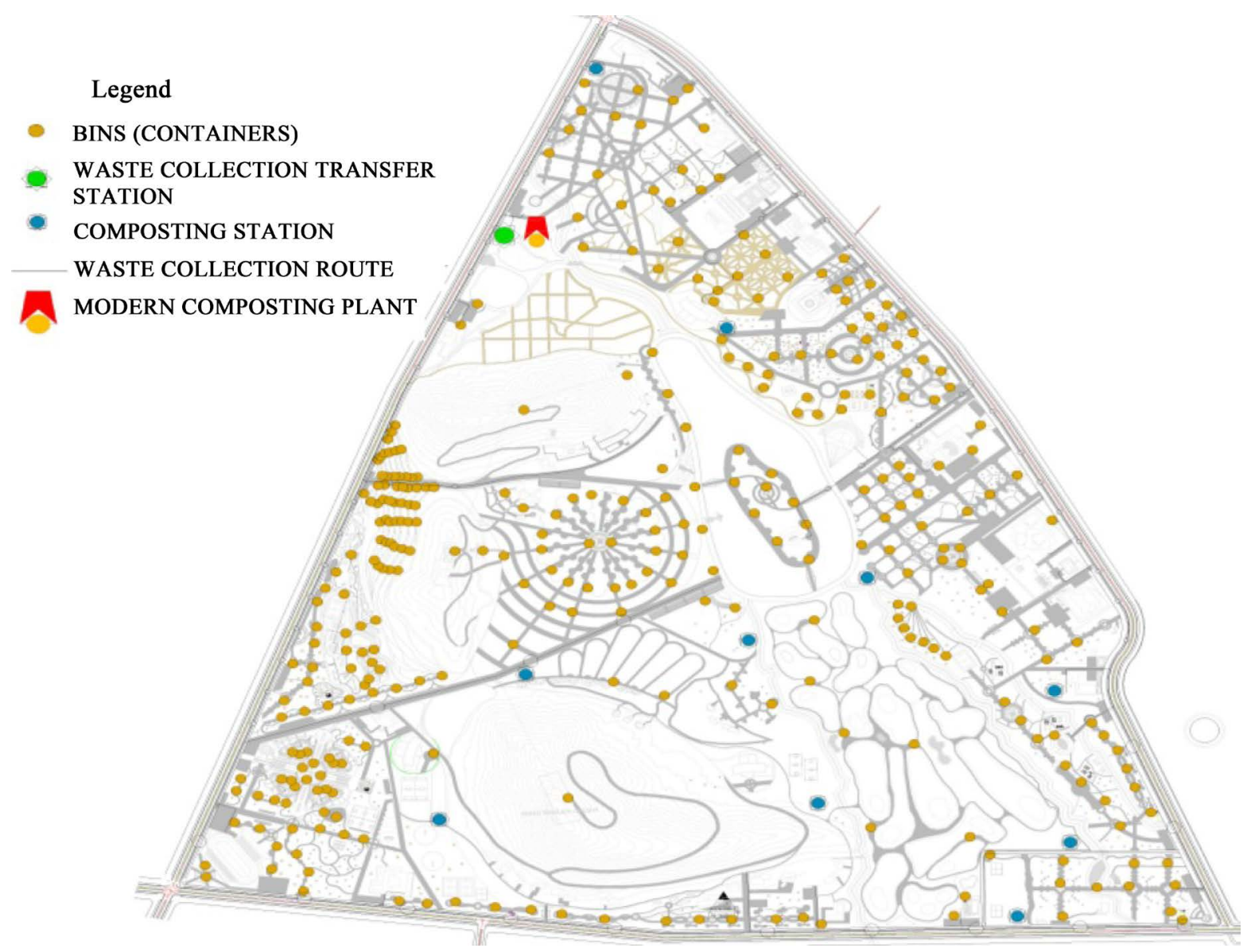

Figure 4. Waste Containers possible sites, composting and transfer station proposed sites. 


\section{Acknowledgements}

We would like to acknowledge Urban Planning division of DCDA for their contributions and efforts, and in addition, with the company of the PDCSR (Principal Design \& Construction Solutions) \& RICL (Regional, International Consulting Ltd) for their efforts in the Solid Waste Management of central park. Furthermore, we would like to acknowledge Jalal-ud-Din Nasiry Director of Natural Heritage Protection Division NEPA Afghanistan in this regards, his help is admirable.

\section{References}

[1] Godbey, G., Graefe, A.R. and James, S.W. (1992) The Benefits of Local Recreation and Park Services, a Nationwide Study of the Perceptions of the American Public (National-Recreation). National Recreation and Park Association, Ashburn.

[2] Meisel, F. and Thiele, N. (2014) Where to Dispose of Urban Green Waste? Transportation Planning for the Maintenance of Public Green Spaces. Transportation Research Part A: Policy and Practice, 64, 147-162. http://dx.doi.org/10.1016/j.tra.2014.03.012

[3] Tyrväinen, L. and Väänänen, H. (1998) The Economic Value of Urban Forest Amenities: An Application of the Contingent Valuation Method. Landscape and Urban Planning, 43, 105-118. http://dx.doi.org/10.1016/S0169-2046(98)00103-0

[4] Chiesura, A. and de Groot, R.S. (2003) Critical Natural Capital: A Socio-Cultural Perspective. Ecological Economics, 44, 219-231. http://dx.doi.org/10.1016/S0921-8009(02)00275-6

[5] Ulrich, R. (1984) View through a Window May Influence Recovery. Science, 224, 224-225. http://dx.doi.org/10.1126/science.6143402

[6] Hartig, T., Mang, M. and Evans, G. (1991) Restorative Effects of Natural Environments Experiences. Environment and Behavior, 23, 3-26. http://dx.doi.org/10.1177/0013916591231001

[7] Ulrich, R.S. (1981) Natural versus Urban Sciences: Some Psycho-Physiological Effects. Environment and Behavior, 13, 523-556. http://dx.doi.org/10.1177/0013916581135001

[8] Kaplan, R. (1985) The Analysis of Perception via Preference: A Strategy for Studying How the Environment Is Experienced. Landscape Planning, 12, 161-176. http://dx.doi.org/10.1016/0304-3924(85)90058-9

[9] Kuo, F.E., Bacaioca, M. and Sullivan, W.C. (1998) Transforming Inner City Landscapes: Trees, Sense of Safety, and Preferences. Environment and Behavior, 1, 28-59. http://dx.doi.org/10.1177/0013916598301002

[10] Tajima, K. (2003) New Estimates of the Demand for Urban Green Space: Implications for Valuing the Environmental Benefits of Boston's Big Dig Project. Journal of Urban Affairs, 25, 641-655. http://dx.doi.org/10.1111/j.1467-9906.2003.00006.x

[11] Kuo, F.E. and Sullivan, W.C. (2001) Environment and Crime in the Inner City Does Vegetation Reduce Crime? Environment and Behavior, 33, 343-367. http://dx.doi.org/10.1177/00139160121973025

[12] Coley, R., Kuo, F. and Sullivan, W. (1997) Where Does Community Grow? The Social Context Created by Nature in Urban Public Housing. Environment and Behavior, 29, 468-494. http://dx.doi.org/10.1177/001391659702900402

[13] Luttik, J. (2000) The Value of Trees, Water and Open Spaces as Reflected by House Prices in the Netherlands. Landscape and Urban Planning, 48, 161-167. http://dx.doi.org/10.1016/S0169-2046(00)00039-6

[14] Woudstra, J. and Fieldhouse, K. (2000) Regeneration of Public Parks'. E \& FN Spon, London.

[15] Formoli, T.A. (1995) Impacts of the Afghan-Soviet War on Afghanistan's Environment. Environmental Conservation, 22, 66-69. http://dx.doi.org/10.1017/S0376892900034093

[16] Lindsey, G. (2003) Sustainability and Urban Greenways: Indicators in Indianapolis. Journal of the American Planning Association, 69, 165-180. http://dx.doi.org/10.1080/01944360308976304

[17] Gallardo, A., Carlos, M., Peris, M. and Colomer, F.J. (2014) Methodology to Design a Municipal Solid Waste Generation and Composition Map: A Case Study. Waste Management, 34, 1920-1931. http://dx.doi.org/10.1016/j.wasman.2014.05.014

[18] Safi, L., Safi, A.G. and Ghafurry, A.S. (2012) The Problem of Homelessness in Kabul City. National Center for Policy Research Kabul University, Kabul.

[19] Central Park Conservancy (2011) Report on the Public Use of Central Park. http://www.centralparknyc.org/assets/pdfs/surveyreport_april2011.pdf

[20] Tchobanoglous, G., Theisen, H. and Vigil, S. (1993) Integrated Solid Waste Management Engineering Principles and Management Issues. McGraw-Hill, Inc., Singapore. 
[21] Dawsey, J. (2013) Trash Talk in Central Park: Plastic Trash Cans to Be Replaced with Metal.

[22] (2015) Central Park Conservancy. http://www.centralparknyc.org/

[23] (2014) New York Weather.

http://www.accuweather.com/en/us/new-yorkny/10007/decemberweather/349727?monyr=12/1/2014\&view=table

[24] Peavy, H.S., Rowe, D.R. and Tchobanoglous, G. (1984) Environmental Engineering. McGraw-Hill, Inc. 